\title{
Vasopressin/Serotonin Interactions in the Anterior Hypothalamus Control Aggressive Behavior in Golden Hamsters
}

\author{
Craig F. Ferris, ${ }^{1}$ Richard H. Melloni Jr, ${ }^{1}$ Gary Koppel, ${ }^{2}$ Kenneth W. Perry, ${ }^{2}$ Ray W. Fuller, ${ }^{2}$ and Yvon Delville ${ }^{1}$ \\ ${ }^{1}$ Neuropsychiatric Sciences Program, Department of Psychiatry, University of Massachusetts Medical Center, Worcester, \\ Massachusetts 01655, and 2Lilly Research Laboratories, Eli Lilly and Company, Lilly Corporate Center, \\ Indianapolis, IN 46285
}

\begin{abstract}
Studies in several species of rodents show that arginine vasopressin (AVP) acting through a $\mathrm{V}_{1 \mathrm{~A}}$ receptor facilitates offensive aggression, i.e., the initiation of attacks and bites, whereas serotonin $(5-\mathrm{HT})$ acting through a $5-\mathrm{HT}_{1 \mathrm{~B}}$ receptor inhibits aggressive responding. One area of the CNS that seems critical for the organization of aggressive behavior is the basolateral hypothalamus, particularly the anterior hypothalamic region. The present studies examine the neuroanatomical and neurochemical interaction between AVP and 5-HT at the level of the anterior hypothalamus (AH) in the control of offensive aggression in Syrian golden hamsters. First, specific $\mathrm{V}_{1 \mathrm{~A}}$ and $5-\mathrm{HT}_{1 \mathrm{~B}}$ binding sites in the $\mathrm{AH}$ are shown by in vitro receptor autoradiography. The binding for each neurotransmitter colocalizes with a dense field of immunoreactive AVP and 5-HT fibers and putative terminals. Putative $5-\mathrm{HT}$ synapses on AVP neurons in the area of the $\mathrm{AH}$ are identified by double-staining immuno-
\end{abstract}

cytochemistry and laser scanning confocal microscopy. These morphological data predispose a functional interaction between AVP and 5-HT at the level of the AH. When tested for offensive aggression in a resident/intruder paradigm, resident hamsters treated with fluoxetine, a selective $5-\mathrm{HT}$ reuptake inhibitor, have significantly longer latencies to bite and bite fewer times than vehicle-treated controls. Conversely, AVP microinjections into the $\mathrm{AH}$ significantly shorten the latency to bite and increase biting attacks. The action of microinjected AVP to increase offensive aggression is blocked by the pretreatment of hamsters with fluoxetine. These data suggest that 5-HT inhibits fighting, in part, by antagonizing the aggressionpromoting action of the AVP system.

Key words: fluoxetine; vasopressin; serotonin; anterior hypothalamus; offensive aggression; $V_{1 A}$ receptor; $5-H T_{1 B}$ receptor; serenic; flank marking
Two neurotransmitter systems implicated in the control of aggressive behavior are arginine vasopressin (AVP) and serotonin (5HT). AVP is a neurochemical signal affecting numerous brain functions (DeWied, 1971; Cooper et al., 1979; Pittman et al., 1982; Fehm-Wolfsdorf et al., 1988; Dantzer and Bluthe, 1992), including aggression (Ferris and Potegal, 1988, Koolhaas et al., 1990, 1991; Potegal and Ferris, 1990; Winslow et al., 1993; Delville et al., 1996a,b). For example, microinjection of AVP $\mathrm{V}_{1 \mathrm{~A}}$-receptor antagonist into the anterior hypothalamus $(\mathrm{AH})$ of a hamster causes a dose-dependent inhibition of offensive aggression, i.e., initiated attacks and bites toward a conspecific placed into their home cage (Ferris and Potegal, 1988). Similarly, AVP receptor blockade in the $\mathrm{AH}$ significantly reduces aggression between hamsters paired together in a neutral arena (Potegal and Ferris, 1990).

Although AVP facilitates offensive aggression, 5-HT is reported to have the opposite effect and diminishes aggressive behavior (for review, see Olivier and Mos, 1990). For example, rats show an increase in offensive aggression after treatment with neurotoxins that deplete 5-HT levels in the hypothalamus (Vergnes et al., 1988). Conversely, rats treated with eltoprazine, a $5-\mathrm{HT}_{1}$ receptor agonist, show a dose-dependent decrease in offensive aggression (Sijbesma et al., 1990). Several

\footnotetext{
Received Oct. 11, 1996; revised Feb. 12, 1997; accepted March 21, 1997.

This work was supported by National Institute of Mental Health Grant MH-52280 to C.F.F.

Correspondence should be addressed to Dr. Craig F. Ferris, Department of Psychiatry, University of Massachusetts Medical Center, 55 Lake Avenue North, Worcester, MA 01655.

Copyright (C) 1997 Society for Neuroscience 0270-6474/97/174331-10\$05.00/0
}

studies have reported elevations in CNS levels of 5-HT after treatment with the selective 5-HT reuptake inhibitor fluoxetine (Guan and McBride, 1988; Auerbach et al., 1989; Perry and Fuller, 1992). Because activation of 5-HT 1 receptors decreases aggressive behavior, it is not surprising that the general elevation of extracellular levels of 5-HT in the CNS by selective 5-HT reuptake inhibitors also diminishes aggressive behavior (Ogren et al., 1980; Olivier et al., 1989; Coccaro et al., 1990; Haug et al., 1990; Ferris and Delville, 1994; Kavoussi et al., 1994; Sanchez and Hyttel, 1994; Delville et al., 1996a); however, the neural substrates and mechanism(s) of action of selective 5-HT reuptake inhibitors on aggressive behavior remain unclear. It is possible that elevated brain levels of 5-HT inhibit the activity of the AVP system, resulting in a decrease in aggressive behavior.

The present studies were undertaken to examine the notion that AVP and 5-HT interact in the AH to control offensive aggression. We propose that AVP facilitates aggression and 5-HT functions to inhibit the activity of the AVP system in the $\mathrm{AH}$. To test this hypothesis, in vitro receptor binding and immunohistochemistry were used to examine the neuroanatomical relationship between AVP/5-HT neurotransmitter systems in the hypothalamus. Specifically, AVP $\mathrm{V}_{1 \mathrm{~A}}$ and 5-HT ${ }_{1 \mathrm{~B}}$ receptors and AVP and 5-HT fibers and terminals were visualized in the AH. In addition, putative 5-HT synapses were visualized on AVP neurons in the area of the AH by doublestaining immunofluorescence and laser scanning confocal microscopy. Then, to examine the functional interaction between these transmitter systems in the $\mathrm{AH}$, resident males were 
stimulated to fight in response to AVP microinjected into the $\mathrm{AH}$ in the presence and absence of fluoxetine.

\section{MATERIALS AND METHODS}

\section{Animals}

Male golden hamsters (Mesocricetus auratus) (110-120 gm) obtained from Harlan Sprague Dawley Laboratories (Indianapolis, IN) were housed individually, maintained on a reverse light/dark cycle (14 hr light/10 hr dark; lights on at 7 P.M.), and provided food and water ad libitum. Animals were acclimated to the reverse light/dark cycle for at least 2 weeks before they were tested. All behavioral tests were conducted during the dark phase of the circadian cycle because of the nocturnal activity of golden hamsters (DeCoursey, 1964; Zucker and Stephan, 1973).

All animals were acquired and cared for in accordance with the guidelines published in the National Institutes of Health Guide for the Care and Use of Laboratory Animals (National Institutes of Health Publications No. 80-23, Revised 1978).

\section{AVP and 5-HT receptor binding autoradiography}

AVP binding sites in the AH were labeled as described previously (Ferris et al., 1993) and modified slightly for these studies. Animals $(n=3)$ were killed by decapitation, and the brains were removed, frozen on dry ice, and stored at $-80^{\circ} \mathrm{C}$. Coronal sections $(20 \mu \mathrm{m})$ were cut at $-10^{\circ} \mathrm{C}$ in a cryostat, thaw-mounted onto gelatin-coated slides, and air-dried at room temperature for no more than $90 \mathrm{~min}$. Tissue sections were held in slide boxes in evacuated freezer bags containing calcium carbonate granules as desiccant. On the day of the experiment, sections were warmed to room temperature for $\sim 90 \mathrm{~min}$ and preincubated at room temperature in 0.05 $\mathrm{M}$ Tris- $\mathrm{HCl}$ buffer, $\mathrm{pH} 7.3$, containing $100 \mu \mathrm{M} \mathrm{NaCl}$ and $100 \mu \mathrm{M}$ guanosine 5'-triphosphate (Type 11-S, catalog no. G8752; Sigma, St. Louis, MO) to uncouple any endogenous AVP from receptors. Sections were then washed for two 5 min periods in Tris buffer, and incubated for $1 \mathrm{hr}$ at room temperature in Tris buffer containing $10 \mathrm{mM} \mathrm{MgCl}, 0.01 \%$ bovine serum albumin (Fraction V, catalog no. A7906; Sigma), $0.05 \%$ bacitracin, and $40 \mathrm{IU}$ aprotinin and $50 \mathrm{pm}\left[{ }^{125} \mathrm{I}\right]-\left[\mathrm{D}\left(\mathrm{CH}_{2}\right)_{5} \mathrm{Sar}^{7}\right] \mathrm{AVP}$ ( ${ }^{125}$ I-SAVP) (Grzonka et al., 1983). Next, sections were washed in icecold Tris buffer containing $10 \mathrm{~mm} \mathrm{MgCl}_{2}$ and $0.2 \%$ paraformaldehyde, with a final wash in ice-cold distilled water to remove any residual salts. Nonspecific binding was obtained by incubations containing $1 \mu \mathrm{M}$ unlabeled AVP. Once they were dried at room temperature, the sections were apposed to Hyperfilm ${ }^{3} \mathrm{H}$ (Amersham, IL), in x-ray cassettes for 2-3 weeks at $-80^{\circ} \mathrm{C}$. After removal from the $\mathrm{x}$-ray cassettes, the sections were counterstained with thionin to identify the neuroanatomical location of the labeled sites.

5-HT binding sites in the $\mathrm{AH}$ were labeled with a selective $5-\mathrm{HT}_{1 \mathrm{~B}}$ ligand, $\left[{ }^{125} \mathrm{I}\right]$-iodocyanopindolol ([$\left.\left.{ }^{125} \mathrm{I}\right] \mathrm{CYP}\right)$ (Hoyer et al.,1985), using the method described above. The incubation, however, was performed in the presence of $30 \mu \mathrm{M}$ isoprenaline to suppress binding to the $\beta$-adrenoreceptors. Nonspecific binding was obtained in the presence of $1 \mu \mathrm{M}$ unlabeled 5-HT during the incubation.

\section{AVP immunohistochemistry}

Hamsters $(n=4)$ were decapitated, and their brains were quickly taken out and fixed by immersion in $10 \%$ acrolein (Aldrich Chemical Company, Milwaukee, WI) in $0.1 \mathrm{~m}$ potassium phosphate buffer (KPBS), $\mathrm{pH}$ 7.2 , for a period of $6 \mathrm{hr}$. Later, the brains were kept overnight in $20 \%$ sucrose/KPBS. The brains were sliced at $40 \mu \mathrm{m}$ in a freezing microtome, and the sections were saved in $0.05 \mathrm{M}$ Tris buffered saline (TBS), $\mathrm{pH}$ 7.6. Immunocytochemistry for AVP was performed on the sections as described previously (Delville et al., 1994). Briefly, the sections were pretreated with $1 \%$ sodium borohydrite (to eliminate residual aldehydes), followed by a preincubation in $20 \%$ normal goat serum containing $1 \%$ hydrogen peroxide and $0.3 \%$ Triton X-100 (to block nonspecific labeling and to eliminate endogenous peroxide, respectively). The sections were then incubated in primary antiserum for AVP (rabbit anti-AVP, 1/16,000; ICN ImmunoBiologicals, Lisle, IL) containing $2 \%$ normal goat serum and $0.3 \%$ Triton $\mathrm{X}-100$ for $1 \mathrm{hr}$ at $37^{\circ} \mathrm{C}$. After they were washed in TBS, the sections were incubated in the secondary antiserum (biotinylated goat anti-rabbit IgG; Vector, Burlingame, CA) and labeled with diaminobenzidine (DAB; $0.5 \mathrm{mg}$ / $\mathrm{ml}$ ) using the Vectastain ABC Elite kit (Vector). Omission of the primary antibody or preincubation of the primary antibody with AVP $(50 \mu \mathrm{M})$ prevented the immunolabeling.

\section{5-HT immunocytochemistry}

Hamsters $(n=4)$ were anesthetized by intraperitoneal injection of sodium pentobarbital, and the brains were fixed by transcardial perfusion with $0.9 \%$ heparinized saline followed by $4 \%$ paraformaldehyde in $0.1 \mathrm{M}$ PBS. The brains were taken out, post-fixed in $4 \%$ paraformaldehyde for 30-60 min, and kept overnight at $4^{\circ} \mathrm{C}$ in $20 \%$ sucrose in $0.1 \mathrm{M}$ PBS. Brain sections were processed for immunocytochemistry to 5-HT after the procedure outlined above for AVP. After preincubation, the sections were incubated in the primary antibody (rabbit anti-5-HT, 1/1000; Eugene Tech International, Ridgefield Park, $\mathrm{NJ}$ ) at $40^{\circ} \mathrm{C}$ for at least $48 \mathrm{hr}$. Later sections were incubated in the secondary antibody (biotinylated goat anti-rabbit, Vector) and labeled with nickelconjugated DAB after tertiary incubation (Vectastain ABC Elite kit, Vector). This procedure resulted in a blue/black labeling of fibers and varicosities in the forebrain. Omission of the primary antibody prevented any labeling.

\section{Double-immunofluorescence labeling}

Double labeling for AVP and 5-HT was performed in $4 \%$ paraformaldehyde-fixed tissue, following a method modified from above. The sections were first labeled for 5-HT using a goat anti-5-HT (1/200; Incstar, Stillwater, MN). After incubation in the primary antibody, the sections were incubated in a biotinylated secondary antibody (horse anti-goat IgG, Vector) and labeled by incubation in Texas Redconjugated avidin D (Vector). Then, the sections were successively incubated in the primary antibody for AVP (rabbit anti-AVP, 1/2000, ICN), another secondary antibody (biotinylated donkey anti-rabbit IgG; Jackson ImmunoResearch Laboratories, West Grove, PA), before being labeled by incubation in FITC-conjugated avidin D (Vector).

Using this double-labeling procedure we noted some cross-reactivity between the FITC-conjugated avidin and Texas Red-conjugated avidin in 5-HT neurons in the dorsal raphe nucleus. This would suggest that FITC may have displaced some of the Texas Red labeling in this area of the brain. The Texas Red-conjugated avidin never labeled AVP neurons, however, and there was no cross-reactivity between fluorochromes in the labeling of 5-HT varicosities and AVP neurons in the AH. In later experiments, double-labeling of AVP and 5-HT was performed using secondary antibodies conjugated to FITC or Texas Red (donkey anti-rabbit conjugated to FITC, donkey anti-goat conjugated to Texas Red; Jackson ImmunoResearch Laboratories). With these antibodies there was no cross-reactivity between labels in the raphe nucleus; nevertheless, the same pattern of labeling persisted in the AH, characterized by AVP neurons surrounded by a high density of 5-HT fibers and varicosities.

Digitized serial sections of $0.5 \mu \mathrm{m}$ each of double-labeled immunofluorescent signals were obtained and reconstructed in three-dimension with a Zeiss inverted laser scanning confocal microscope (LSM 410). The data were volume-rendered to enhance the visualization of 5-HT boutons and putative synapses with VoxelView/ULTRA version 2.0 Volume Rendering Software run on a Silicon Graphics IRIS Indigo XS24Z/Elan work station.

\section{Behavioral assays and drug treatments}

Flank marking. Vasopressin is a neurotransmitter critical to the activation of flank marking, a stereotyped motor behavior used by hamsters to disseminate odors in the environment (Johnston, 1975; Ferris et al., 1984). Injecting AVP into the AH triggers intense flank marking behavior (Ferris et al., 1984), whereas blocking the $\mathrm{V}_{1 \mathrm{~A}}$ receptor in this site inhibits flank marking induced by odors and agonistic encounters (Ferris et al., 1985, 1986a; Albers et al., 1986). The present studies were designed to test the hypothesis that 5-HT diminishes aggression by inhibiting the activity of the AVP system at the level of AH. To this end, we used odor-induced flank marking to screen for a dose of fluoxetine that might block the central activity of AVP.

Hamsters $(n=11)$ were tested for odor-induced flank marking $1 \mathrm{hr}$ after an intraperitoneal injection of vehicle (25\% DMSO in $0.9 \%$ saline) or $0.2,2.0$, and $20 \mathrm{mg} / \mathrm{kg}$ fluoxetine given in a volume of $0.2 \mathrm{ml}$. Behavioral testing was performed in one of four Plexiglas cages $(24 \times$ $32 \times 20 \mathrm{~cm})$ soiled by the odors of other hamsters. All studies were counterbalanced; each animal received injections of vehicle and varying concentrations of fluoxetine every fourth day over a period of $16 \mathrm{~d}$. Animals were exposed only once to each of the four soiled cages. A flank mark was scored each time a hamster rubbed its flank gland against the wall or corner of the cage over a $10 \mathrm{~min}$ test period. It was 
determined that a dose of $20 \mathrm{mg} / \mathrm{kg}$ was effective in blocking odorinduced flank marking. When the effect of fluoxetine on offensive aggression was tested, it was observed that a dose of $10 \mathrm{mg} / \mathrm{kg}$ tested on two animals reduced their total number of bites and increased their latency to bite as compared with vehicle treatment. Hence, in the AVP microinjection studies we used doses of 10 or $20 \mathrm{mg} / \mathrm{kg}$ of fluoxetine as indicated.

Offensive aggression. A resident/intruder paradigm was used to evaluate the role of 5-HT in the control of offensive aggression in hamsters. Hamsters $(n=6)$ were housed individually in Plexiglas cages $(24 \times 32 \times$ $20 \mathrm{~cm}$ ) for a minimum of 4 weeks. The hamsters chosen for this study were established breeders. In addition, they were experienced fighters, and they routinely attacked intruders placed in their home cage. On the day of testing, these resident animals were given an intraperitoneal injection of fluoxetine $(20 \mathrm{mg} / \mathrm{kg})$ or vehicle in a volume of $0.2 \mathrm{ml}$. One hour later, a smaller male intruder was placed into the home cage of the resident. The resident was scored for latency to bite the intruder, total number of bites, and total contact time with the intruder over a $10 \mathrm{~min}$ test period. All experiments were observed and videotaped under dim red illumination. Each resident was tested with both fluoxetine and vehicle, with 1 week between treatments. The study was counterbalanced and no resident saw the same intruder more than once.

To control for nonspecific effects of fluoxetine on animal behavior, sexual motivation and activity in an open field were also measured. Briefly, immediately after testing for offensive aggression, the intruder was removed and replaced by a female hamster in estrus. Within moments of entering the cage, the female would lordose in response to the tactile exploration of the resident male. The male was timed for latency to mount and thrust the female from the time the female was placed into the cage. The encounter was stopped before intromission and ejaculation. After the test for sexual motivation, the resident male was placed into a vacated cage soiled with the odors of conspecifics and tested for flank marking as described above. Immediately afterward, the resident hamster was placed into a large clean Plexiglas cage $(48 \times 32 \times 40 \mathrm{~cm})$ devoid of any bedding. This "open field" was delineated into equal quadrants by tape on the underside of the cage. Animals were scored for motor activity by counting the number quadrants traversed in $1 \mathrm{~min}$. A two-tailed paired $t$ test was used to compare the latency to bite, contact time, sexual motivation, and motor activity between treatments. A Wilcoxon matchedpairs signed ranks test (two-tailed) was used to compare the total number of bites and flank marks between treatments.

\section{Microinjection studies}

This study was designed to examine the effect of fluoxetine on offensive aggression facilitated by the microinjection of AVP in the AH. Hamsters $(n=10)$ were anesthetized with sodium pentobarbital $(50 \mathrm{mg} / \mathrm{kg})$ and stereotaxically implanted with 26 gauge microinjection guide cannulae aimed at the $\mathrm{AH}$ as described previously (Ferris et al., 1986a). The stereotaxic coordinates of the AH were $1.0 \mathrm{~mm}$ anterior to bregma, 1.8 $\mathrm{mm}$ lateral to the midsagittal suture, $7.5 \mathrm{~mm}$ ventral from dura, and angled at $8^{\circ}$. The interaural line was held at zero with the incisor bar. All hamsters were allowed to recover from surgery for at least $2 \mathrm{~d}$ before testing. The animals selected for this study were experienced breeders and fighters, as noted earlier. Animals were tested for offensive aggression after each of three different treatments: (1) vehicle microinjection in the absence of fluoxetine, (2) AVP microinjection in the presence of fluoxetine, and (3) AVP microinjection in the absence of fluoxetine. The treatment schedule was counterbalanced, and animals were tested once every $5 \mathrm{~d}$ over a 15 day period. On the day of testing, animals were pretreated with intraperitoneal injections of vehicle (25\% DMSO in $0.9 \%$ $\mathrm{NaCl})$ or fluoxetine $(10 \mathrm{mg} / \mathrm{kg})$ in a volume of $0.2 \mathrm{ml}$. Approximately 60-90 min later, the hamsters were microinjected in the AH with either AVP $(0.09 \mu \mathrm{M}$ in $0.9 \% \mathrm{NaCl})$ or saline vehicle in a volume of $100 \mathrm{nl}$. The injections were given through a 33 gauge needle attached to a $1 \mu \mathrm{l}$ Hamilton syringe by PE-20 tubing. All microinjections were performed on unanesthetized animals and took no longer than $15 \mathrm{sec}$. After microinjection, animals were returned to their home cage. Two minutes later, a smaller male was introduced, and the resident was scored for latency to bite, total bites, and total contact time.

At the conclusion of the microinjection study, animals were killed, and the brains were fixed by immersion in $10 \%$ formalin and sectioned on a vibratome. The position of the tip of the needle for each microinjection site was determined on $100 \mu \mathrm{m}$ transverse sections stained with thionin.

Critical to these studies was the microinjection of AVP in a concentration of $0.09 \mu \mathrm{M}$. Although blockade of AVP receptor in the AH inhibits offensive aggression (Ferris and Potegal, 1988), microinjection of AVP into the $\mathrm{AH}$ in concentrations ranging from 0.27 to $27 \mu \mathrm{M}$ triggers intense flank marking (Ferris et al., 1988). Resident hamsters treated with concentrations of AVP in excess of $0.9 \mu \mathrm{M}$ flank mark frantically and ignore intruders placed into their home cage (C. Ferris, unpublished observation). Thus, the dose of AVP tested in this study was below the threshold dose used to trigger flank marking.

The latency to bite was evaluated with a repeated measures ANOVA followed by a paired $t$ test (two-tailed) for significance between treatments. Total bites were analyzed with nonparametric statistics (Friedman Test followed by Wilcoxon).

\section{RESULTS}

\section{AVP/5-HT interactions in the AH}

The receptor autoradiogram shown in Figure 1 reveals specific $\mathrm{V}_{1 \mathrm{~A}}$ binding sites in the area of the $\mathrm{AH}$ that extends laterally into the lateral hypothalamus and ventrally to the optic chiasm. In comparison, Figure 1 also shows a more diffuse pattern of specific $5-\mathrm{HT}_{1 \mathrm{~B}}$ binding sites in this area of the hypothalamus. Note the almost homogenous distribution of 5-HT binding sites extending from the third ventricle through the lateral hypothalamus.

In addition to overlapping binding sites for AVP and 5-HT in the area of the $\mathrm{AH}$, there is a dense plexus of immunoreactive fibers for each neurochemical signal as shown in Figure 2. AVP immunoreactive fibers and cell bodies localized to the nucleus circularis (NC) and medial supraoptic nucleus ( $\mathrm{mSON})$ can be seen in and around the AH. Although there is an absence of 5-HT cell bodies in and around the $\mathrm{AH}$, this area is densely innervated by 5-HT fibers and synaptic boutons reflecting the pattern of 5-HT binding.

The AVP cell groups with fibers that project in and around the $\mathrm{AH}$, i.e., $\mathrm{mSON}$ and NC, all have close contact with 5-HT fibers and putative terminals. Visualization with laser scanning confocal microscopy of the AVP neurons in the NC by doubleimmunofluorescent labeling for AVP and 5-HT reveals a dense innervation of 5-HT fibers and synaptic boutons (Fig. 3). Putative 5-HT synapses can be seen along neural processes in a volumerendered data set (Fig. 3).

\section{Fluoxetine affects offensive aggression}

Treatment of six experienced fighters with fluoxetine $(20 \mathrm{mg} /$ $\mathrm{kg}$ ) significantly diminished their offensive aggression, as shown in the top row of Figure 4. After treatment with vehicle, animals had a mean latency to bite intruders of $<20 \mathrm{sec}$ and a median of nine bites in a 10 min observation period. After treatment with fluoxetine, these same animals showed a significant increase $\left(t_{(5)}=11.7 ; p<0.001\right)$ in the latency to bite and a decrease in the number of bites $(Z=2.2$; $p<0.05)$. In fact, five of the six animals did not bite the intruder at all during the $10 \mathrm{~min}$ test period. As expected, fluoxetine treatment significantly $(Z=2.02 ; p<0.05)$ reduced odor-induced flank marking (top row, Fig. 4). Contact time did not differ between treatments $\left(t_{(5)}=1.7 ; p>0.1\right)$; the experienced fighters spent $\sim 3 \mathrm{~min}$ of the $10 \mathrm{~min}$ test period smelling and exploring the intruder, as shown in the bottom row of Figure 4. Similarly, there was no significant difference between treatments $(Z=$ $0.12 ; p>0.1)$ for general motor activity when tested in an open arena (bottom row, Fig. 4). Interestingly, the time it took to mount a receptive female placed into the home cage of the experienced fighters was diminished after fluoxetine treatment, with a trend toward significance $\left(t_{(5)}=2.29 ; p<0.1\right)$.

\section{Fluoxetine inhibits AVP-induced aggressive behavior}

Data on offensive aggression stimulated by the microinjection of AVP into the AH after treatment with fluoxetine or vehicle from 

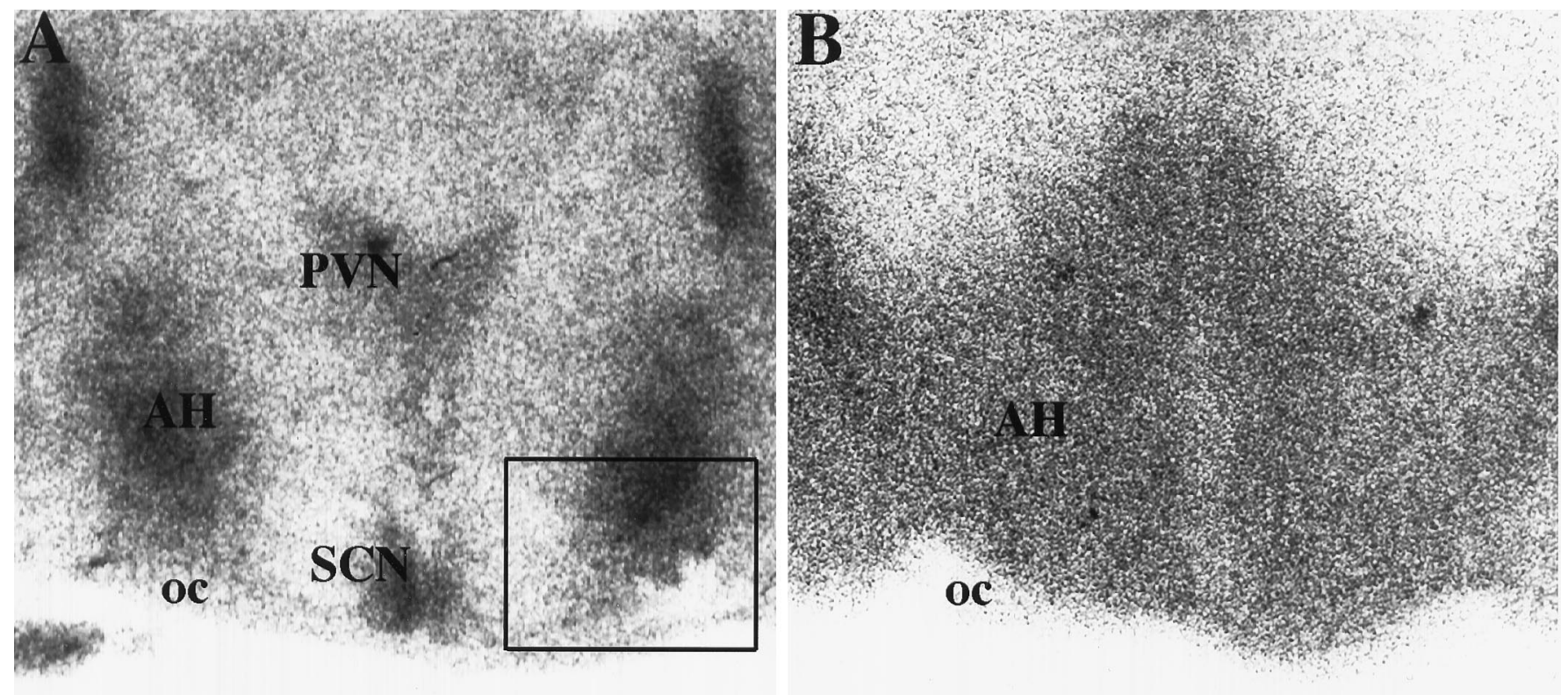

Figure 1. AVP and 5-HT receptor binding in the AH of golden hamsters. Shown are autoradiograms of specific binding for $\left.{ }^{125} \mathrm{I}\right]-\left[\mathrm{D}\left(\mathrm{CH}_{2}\right)_{5} \mathrm{Sar}{ }^{7}\right] \mathrm{AVP}$ $(A)$, a selective AVP $\mathrm{V}_{1 \mathrm{~A}}$ receptor antagonist, and $(-)\left[{ }^{125} \mathrm{I}\right]$ iodocyanopindolol $(B)$, a selective $5-\mathrm{HT}_{1 \mathrm{~B}}$ receptor ligand. The binding shown was performed on contiguous $20 \mu \mathrm{m}$ coronal sections. The area outlined over the $\mathrm{AH}$ in autoradiogram $A$ is the same approximate area shown in the top photomicrograph depicting AVP immunoreactivity in Figure 2. oc, Optic chiasm; PVN, paraventricular nucleus; $S C N$, suprachiasmatic nucleus.

10 experienced fighters is shown in Figure 5. There was a significant difference between treatments for both latency to bite $\left(F_{(2,29)}=30.7 ; p<0.001\right)$ and number of bites $\left(\chi^{(2)}=18.2 ; p<\right.$ $0.001)$. When injected with saline vehicle into the AH after intraperitoneal vehicle treatment $(V e h+V e h)$, resident animals showed a mean latency of just over 2 min to bite the intruder. When the same animals were microinjected with AVP into the $\mathrm{AH}$ after intraperitoneal vehicle treatment, the mean latency to bite was reduced by $\sim 40 \%$. In the presence of fluoxetine, however, AVP-injected animals showed a latency to bite that was $>400 \%$ greater than vehicle treatment. The number of biting attacks was also significantly influenced by each treatment. Animals with vehicle treatments showed a median of six bites over a 10 min test period. With AVP treatment the median number of bites increased by twofold $(p<0.05)$; however, treatment with fluoxetine essentially abolished the effect of AVP on the number of bites. Six of the 10 experienced fighters failed to bite in the 10 min test period, whereas the remaining animals could muster only one or two bites with AVP microinjection.

\section{DISCUSSION}

The data from this study support the notion that 5-HT diminishes offensive aggression in golden hamsters, in part, by blocking the activity of the AVP system in the area of the AH (a model of this interaction is provided in Fig. 6). To accomplish this, we propose that 5-HT is acting directly on aggression-facilitating neurons in the AH to inhibit the excitatory action of AVP neurotransmitter. In addition, we propose that 5-HT is acting indirectly on aggression-facilitating neurons in the $\mathrm{AH}$ by inhibiting the activity of AVP neurons in the NC and mSON. These populations of neurons have been identified previously as potential sources of AVP neurotransmitter in the $\mathrm{AH}$ involved in the control of agonistic behavior (Ferris et al., 1989, 1990, 1992). The arguments supporting this hypothesized interaction between AVP and 5-HT are discussed below.

The possibility that AVP and 5-HT innervate the same neurons in the $\mathrm{AH}$ involved in the integration and motor control of offensive aggression is supported by the neuroanatomical and neuropharmacological data showing a strong presence of both neurotransmitter systems in the $\mathrm{AH}$. Both $\mathrm{V}_{1 \mathrm{~A}}$ and 5-HT $\mathrm{T}_{1 \mathrm{~B}}$ binding sites are present in the AH and colocalize with a dense plexus of AVP and 5-HT fibers and putative terminals. Furthermore, the ability of AVP to facilitate offensive aggression when microinjected into the $\mathrm{AH}$ is blocked after fluoxetine treatment. This would indicate that 5-HT can inhibit the action of AVP after it is released from AVP neurons; however, the present studies using peripheral injection of fluoxetine do not limit the action of 5-HT to the AH. It is very possible that the global elevation of 5-HT after treatment with a specific 5-HT reuptake inhibitor affects multiple sites in the neural network regulating aggression. In preliminary studies, we have noted that 5-HT injected together with AVP into the AH blocks the flank marking triggered by the exogenous neuropeptide (C. Ferris, unpublished data). This would indicate that 5-HT can directly antagonize an AVP-dependent behavior at the level of the $\mathrm{AH}$.

The primary inhibitory effect of 5-HT on aggression is mediated through the postsynaptic $5-\mathrm{HT}_{1 \mathrm{~B}}$ receptor subtype (Sijbesma et al., 1991; Olivier et al., 1995). The importance of the 5-HT receptor was corroborated in a recent study reporting that homozygous mutant mice lacking the $5-\mathrm{HT}_{1 \mathrm{~B}}$ receptor show enhanced aggression toward intruders (Saudou et al., 1994). Because postsynaptic $5-\mathrm{HT}_{1 \mathrm{~B}}$ receptors seem to be fundamental in the modulation of offensive aggression, it is reasonable to postulate that 5-HT activates these receptors, making a neuron coinnervated by AVP unresponsive to the excitatory effects of the neuropeptide. AVP is reported to enhance neuronal excitability in the hippocampus (Muhlethaler et al., 1982), sympathetic ganglia 


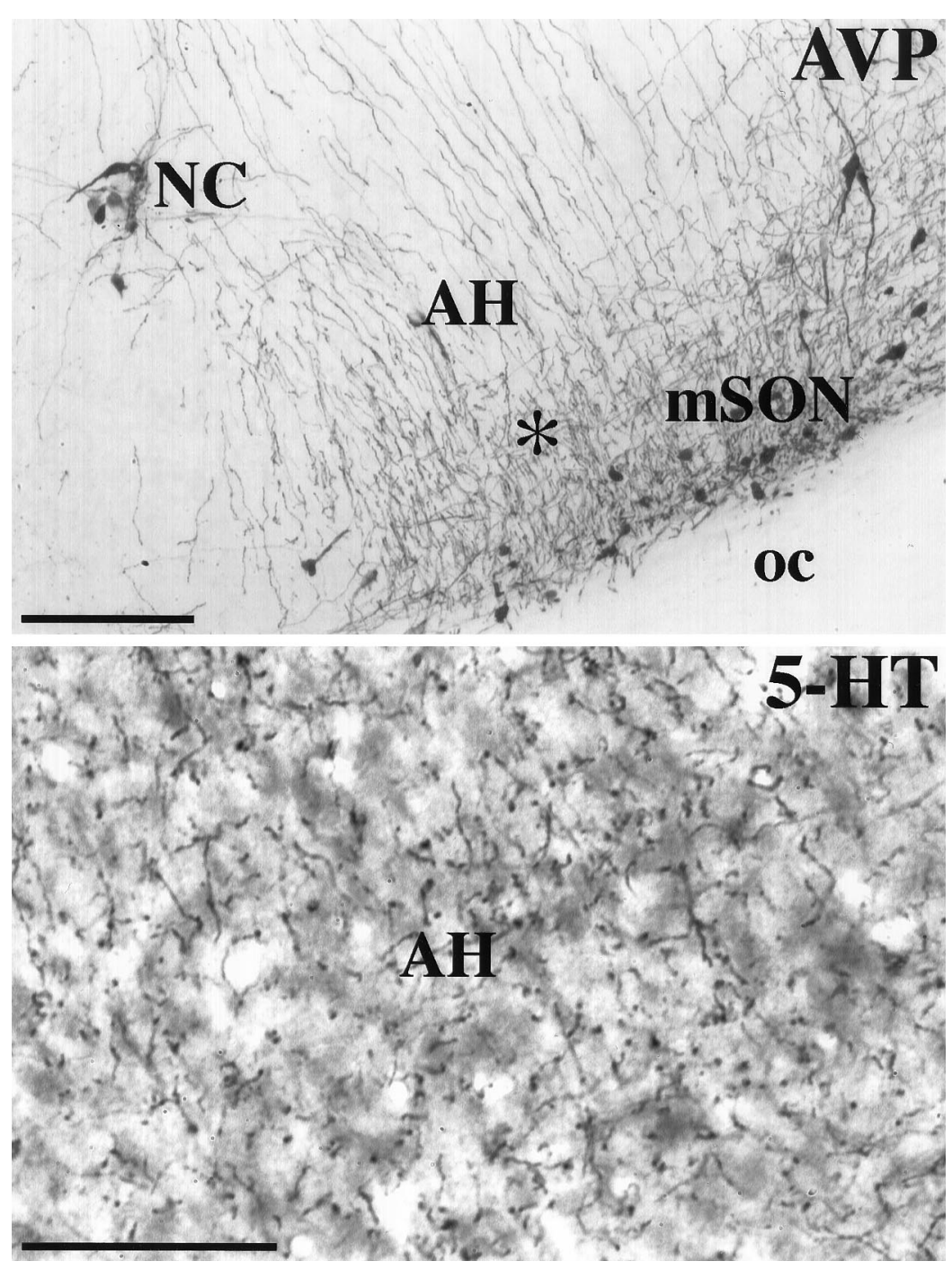

Figure 2. Light-field photomicrographs of coronal sections through the golden hamster hypothalamus. Shown are arginine vasopressin $(A V P)$ and serotonin $(5-H T)$ immunoreactivity associated with the anterior hypothalamus $(A H)$. The star shown in the AVP photomicrograph depicts the same approximate area shown in the bottom photomicrograph of 5-HT immunoreactivity. Scale bars: top, $200 \mu \mathrm{m}$; bottom, 75 $\mu \mathrm{m}$. $N C$, Nucleus circularis; $m S O N$, medial supraoptic nucleus; oc, optic chiasm.
(Peters and Kreulen, 1985), lateral septum (Raggenbass et al., 1988), nucleus of the solitary tract (Raggenbass et al., 1989), paraventricular nucleus (Carette and Poulain, 1989), and suprachiasmatic nucleus (Liou and Albers, 1989). From a mechanistic standpoint, AVP acting through a $\mathrm{V}_{1}$-like receptor can generate a persistent inward sodium current when applied to facial motoneurons (Raggenbass et al., 1991). This depolarizing current is voltage-gated and tetrodotoxin insensitive and contributes to sustained depolarizing potentials that may facilitate repetitive firing. The intracellular mechanisms for this AVP-mediated depolarizing current is unknown but may be regulated, in part, by increases in cAMP (Green and Gillette, 1983). Raggenbass and coworkers (1991) propose that AVP may indirectly increase cAMP levels through $\mathrm{V}_{1 \mathrm{~A}}$-coupled activation of phospholipase $\mathrm{C}$ and suppression of guanine nucleotide-binding protein inhibition of adenylate cyclase.

5-HT acting through the 5- $\mathrm{HT}_{1 \mathrm{~B}}$ receptor can inhibit forskolinstimulated adenylate cyclase activity in the substantia nigra (Bouhelal et al., 1988; Schoeffter and Hoyer, 1989). In various cell lines, the $5-\mathrm{HT}_{1 \mathrm{~B}}$ receptor is reported to mediate the inhibition of cAMP accumulation (Murphy and Bylund, 1989; Giles et al., 1994; Schoeffter et al., 1995). If both $\mathrm{V}_{1 \mathrm{~A}}$ and 5-HT $\mathrm{HB}_{1 \mathrm{~B}}$ receptors appear on the same neurons controlling aggression, it is possible that 5-HT may offset the excitatory effects of AVP, blocking attack behavior.

The potential for 5-HT acting directly on the AVP neuron is also supported by the neuroanatomical data. With doubleimmunostaining for AVP and 5-HT we have identified putative 5-HT synapses on AVP neurons in golden hamsters, particularly in the area of the mSON and NC, two populations of AVP neurons that have been identified as innervating the $\mathrm{AH}$ and are involved in the regulation of agonistic behavior (Ferris et al., 1989, 1990, 1992). The source of 5-HT innervation to the AVP system in the hypothalamus is the nucleus of the raphe (Sawchenko et al., 1983). The presence of putative 5-HT synapses on AVP neurons raises the possibility that fluoxetine can inhibit aggression by diminishing or blocking the electrical activity of AVP neurons and the release of AVP from nerve terminals. More than $30 \%$ of the neurosecretory neurons in the PVN identified by antidromic stimulation of the neurohypophysis are inhibited by microiontophoresis of 5-HT (Moss et al., 1972). This effect is even more robust in the SON, because all cells identified by antidromic stimulation show diminished electrical activity with 5-HT application (Barker et al., 1971). Indeed, peripheral injection of fluoxetine results in an elevation in extracellular 5-HT levels concomitant with a signifi- 

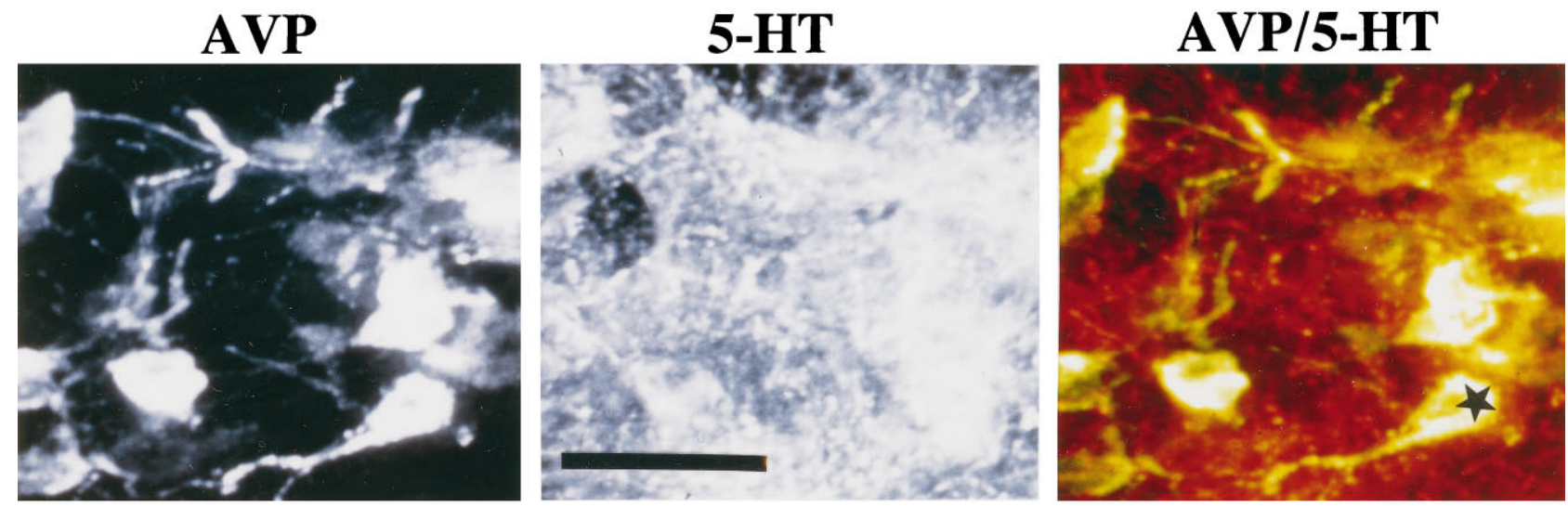

\section{Volume Rendered Data Set}

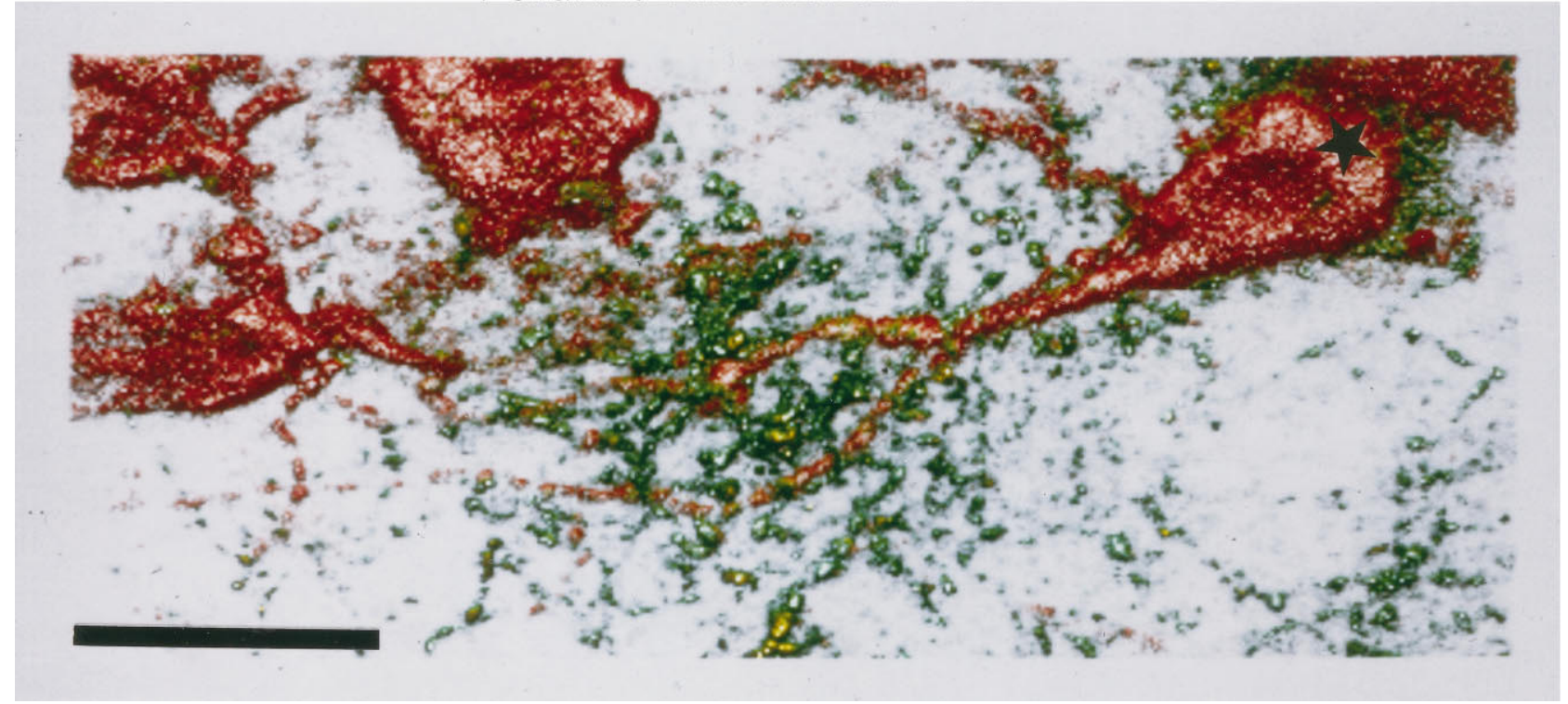

Figure 3. Photomicrographs of arginine vasopressin $(A V P)$ and serotonin (5-HT) revealed by double-labeling immunocytochemistry. Shown are AVP and 5-HT fluorescent immunoreactivity acquired through laser scanning confocal microscopy. The same single optical plane is shown for both neurochemical signals in the top black and white photographs. The combination of both digitized images is shown in color on the top right panel. The AVP is depicted in bright yellow and the 5-HT appears as a red/orange. A volume-rendered data set of serial optical sections through the AVP neuron denoted with the star is shown in the bottom color photograph. The green stippling is 5-HT varicosities and putative synapses clustered around the red-colored AVP neuron (denoted by the star). Scale bars: top, $50 \mu \mathrm{m}$; bottom, $30 \mu \mathrm{m}$.

cance decrease in AVP levels measured in the AH by microdialysis (Ferris, 1996).

The notion that 5-HT might function to inhibit the release of AVP was supported by a recent clinical study of personalitydisordered subjects with a history of "fighting and assault" (Coccaro, 1996). These subjects showed a significant positive correlation between CSF levels of AVP and aggression. In addition, these subjects were judged to have a hyporeactive 5-HT system as assessed by fenfluramine challenge. Fenfluramine is a 5-HT-releasing drug that normally stimulates prolactin release as a neuroendocrine measure of central 5-HT activity. Subjects with a history of inappropriate aggressive behavior show a blunted prolactin release in response to fenfluramine (Coccaro et al., 1989; O'Keane et al., 1992). This would also seem to be true in nonhuman primates: macaque monkeys show increased aggressive gestures that negatively correlate with diminished prolactin release in response to fenfluramine (Kyes et al., 1995). Thus, in humans, a hyporeactive
5-HT system may result in enhanced CNS levels of AVP and the facilitation of impulsive, aggressive behavior.

5-HT has long been considered an important neurotransmitter in the regulation of impulsive and aggressive behavior in humans and nonhuman primates. Subjects with a life history of aggression present with low levels of the 5-HT metabolite 5-hydroxyindolacetic acid (5-HIAA) in their CSF (Brown et al., 1979, 1982). Low levels of 5-HT metabolite are indicative of diminished 5-HT release. Low levels of CSF 5-HIAA also correlate with adult impulsive violent behavior (Linnoila et al., 1983), alcohol-associated violence (Virkkunen et al., 1995), and impulsive disruptive behavior in children (Kruesi et al., 1990). In freeranging rhesus monkeys, low levels of CSF 5-HIAA correlate with increased aggression and risk taking (Higley et al., 1992; Mehlman et al., 1994). The levels of CSF 5-HIAA in talapoin monkeys with an established social hierarchy are the lowest in high ranking animals and highest in subordinates (Yodyingyuad et al., 1985). The high levels of CSF 5-HIAA in subordinates is a persistent 

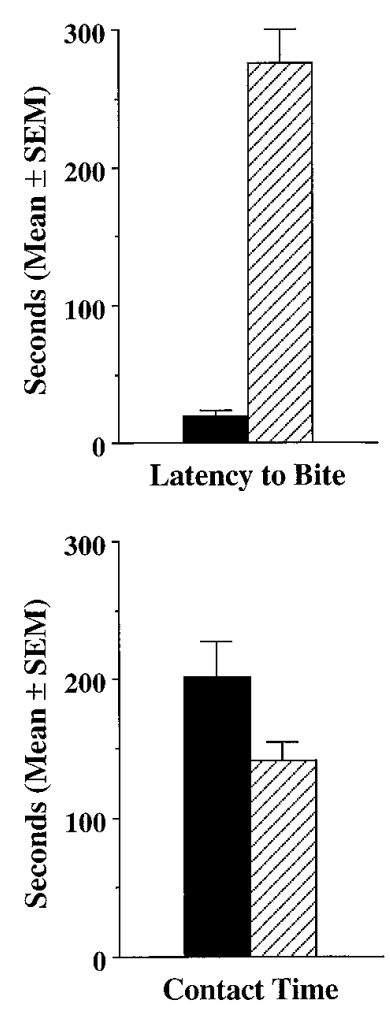
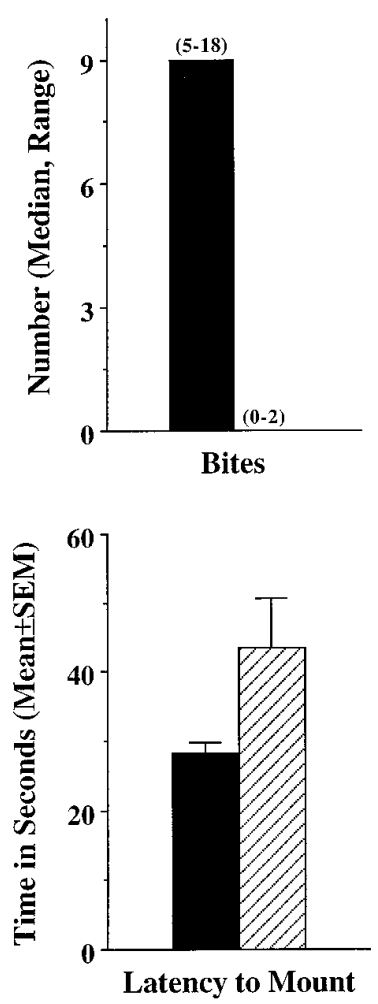
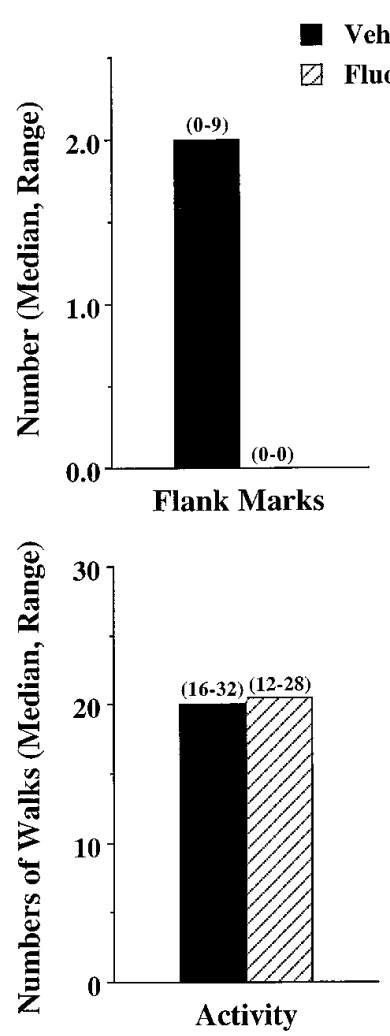

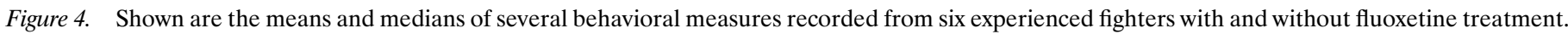

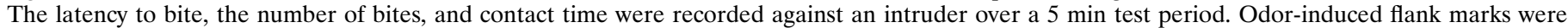

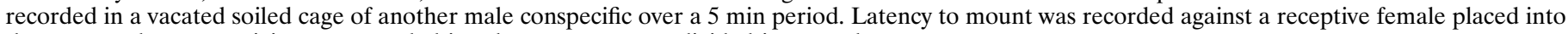
the cage, and motor activity was recorded in a large open arena divided into quadrants.
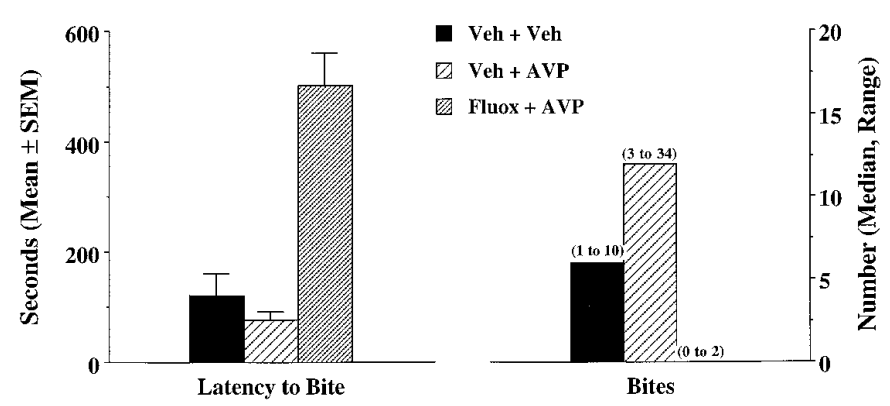

Figure 5. Shown are the means and medians of two measures of offensive aggression. The latency to bite and number of bites were recorded in 10 experienced fighters treated with each of the three injection regimens noted (intraperitoneal injection + anterior hypothalamic microinjection). The behavioral measures were recorded against an intruder over a $10 \mathrm{~min}$ test period.

condition accrued to their low social status characterized by high levels of withdrawal and diminished aggressive and reproductive behavior.

Corroborating the human and monkey studies are neurobiological data from rodents linking 5-HT to the inhibition of aggression responding (Ellison, 1976; McMillen et al., 1987; Vergnes et al., 1988). As mentioned earlier, in a resident/intruder model, eltoprazine, the $5-\mathrm{HT}_{1}$ agonist, produces a dose-dependent decrease in offensive aggression in a rat resident/intruder model without altering other behaviors, including defensive aggression (Sijbesma et al., 1990). This unique pharmacological profile fits a class of drugs called "serenics" (Olivier and Mos, 1990). A serenic would hypothetically reduce or delay the onset of attack behavior without interfering with cognitive, social, appetitive, or sexual behaviors, while retaining the ability to fight back. In the present studies on hamsters, we observed a serenic-like profile for fluoxetine: it significantly decreases offensive aggression in experienced fighters and leaves other behaviors like social interest, sexual activity, and motor activity intact.

Multiple studies have shown AVP to be an important neurotransmitter affecting agonistic behavior associated with the establishment and maintenance of dominant/subordinate relationships between hamsters (for review, see Ferris, 1992). Our results clearly show that hamsters injected with AVP in the AH display a significant increase in offensive aggression toward intruders. Past studies in hamsters, using AVP receptor antagonists microinjected into the $\mathrm{AH}$, produced a dose-dependent inhibition of offensive aggression of a resident male toward an intruder (Ferris and Potegal, 1988) and a decrease in aggression between pairs of conspecifics in a neutral arena (Potegal and Ferris, 1990). The ability of AVP to modulate offensive aggression is not limited to the AH, however. Microinjection of AVP into the ventrolateral hypothalamus of the hamster facilitates offensive aggression (Delville et al., 1996b), and infusion of AVP into the amygdala or lateral septum facilitates offensive aggression in castrated rats (Koolhaas et al., 1990, 1991).

Interestingly, the behavioral effects of blocking AVP receptors in the $\mathrm{AH}$ of hamsters are similar to those of fluoxetine. Not only 


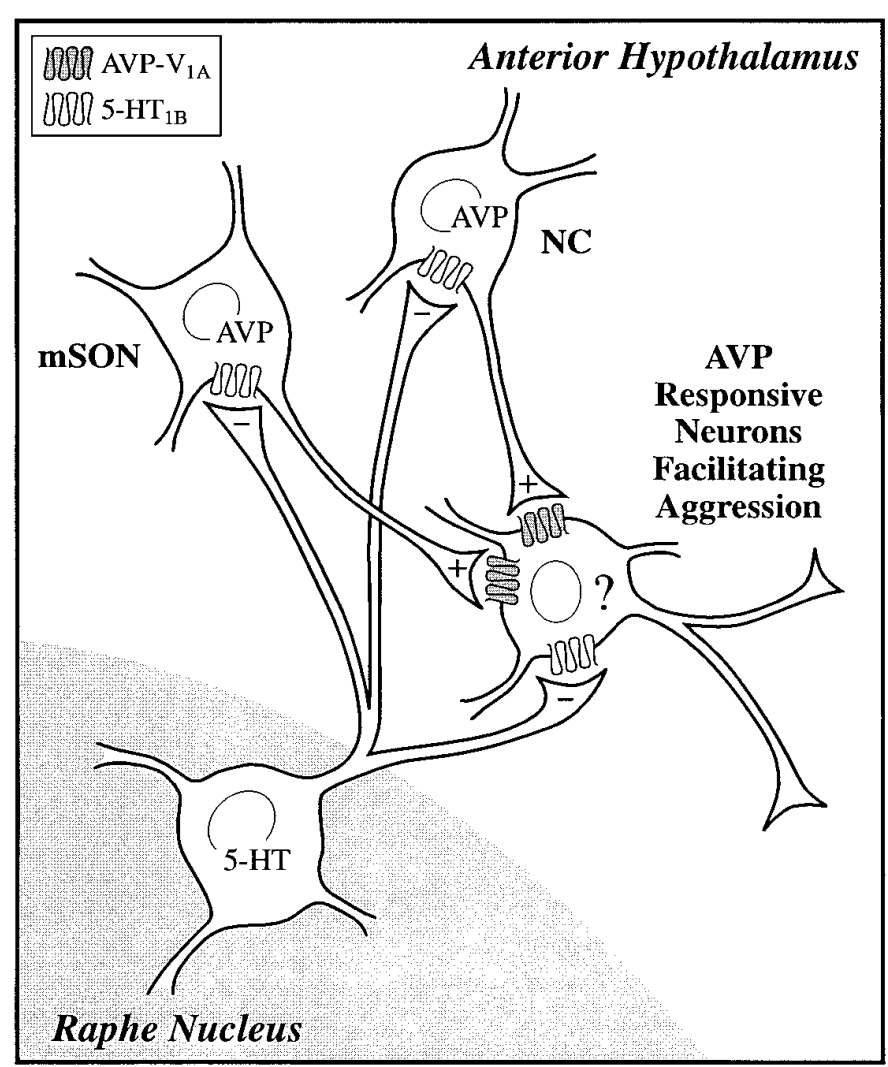

Figure 6. Neurochemical regulation of offensive aggression: a model showing the hypothetical interaction of serotonin $(5-H T)$ with the arginine vasopressin $(A V P)$ system in the AH. 5-HT fibers originating from neurons in the raphe nucleus innervate populations of AVP neurons localized to the medial supraoptic nucleus ( $M S O N)$ and nucleus circularis $(N C)$. These AVP neurons have been identified as potential sources of AVP innervation to the AH involved in agonistic behavior. These AVP neurons together with 5-HT neurons from the raphe nucleus impinge on neurons in the $\mathrm{AH}$ involved in the facilitation of aggression. The identity (?) of these post-synaptic neurons is unknown. 5-HT is inhibitory $(-)$, working through a $5-\mathrm{HT}_{1 \mathrm{~B}}$ receptor, whereas AVP is excitatory $(+)$, working through a $\mathrm{V}_{1 \mathrm{~A}}$ receptor.

does AVP receptor antagonist increase the latency to bite and decrease the total number of bites toward intruders, it also acts like a serenic: other social behaviors, general activity, and sexual behavior are unaffected. Given that AVP can affect numerous brain functions at multiple sites in the CNS, however, it is unlikely that an AVP receptor antagonist blocking all $\mathrm{V}_{1 \mathrm{a}}$ receptors would selectively inhibit offensive aggression independent of other AVPmediated behaviors.

The search for biological mechanisms and anatomical substrates underlying the interactions between functionally opposed neurotransmitter systems is an important aspect of the neurobiology of aggression. The ability of AVP to affect offensive aggression at multiple sites in the CNS of different species is evidence that this neurochemical system may have a broad physiological role in enhancing arousal during stressful agonistic encounters, lowering the threshold for offensive aggression, and facilitating attack behavior. Likewise, 5-HT is broadly distributed throughout the CNS and seems essential for control of impulsivity and aggression in a range of species. 5-HT may have a direct inhibitory effect on the neural network controlling aggression or may act indirectly by depressing the activity of a neurotransmitter system that activates aggression. The present study provides evidence that the anti-aggressive activity of 5-HT may be attributable in part to an inhibitory effect on the AVP system in the $\mathrm{AH}$.

\section{REFERENCES}

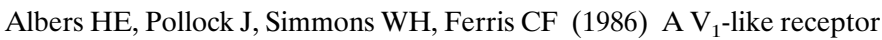
mediates vasopressin induced flank marking behavior within the hamster hypothalamus. J Neurosci 6:2085-2089.

Auerbach SB, Minzenberg MJ, Wilkinson LO (1989) Extracellular serotonin and 5-hydroxyindoleacetic acid in hypothalamus of unanesthetized rats measured by in vivo dialysis coupled to high-performance liquid chromatography with electrochemical detection: dialysate serotonin reflects neuronal release. Brain Res 499:281-290.

Barker JL, Crayton JW, Nicoll RA (1971) Noradrenaline and acetylcholine responses of supraoptic neurosecretory cells. J Physiol (Lond) 218:19-32.

Bouhelal R, Smounya L, Bockaert J (1988) $5-\mathrm{HT}_{1 \mathrm{~B}}$ receptors are negatively coupled with adenylate cyclase in rat substantia nigra. Eur J Pharmacol 151:189-196.

Brown GL, Goodwin FK, Ballenger JC, Goyer PF, Major LF (1979) Aggression in humans correlates with cerebrospinal fluid amine metabolites. Psychiatry Res 1:131-139.

Brown GL, Ebert MH, Goyer PF Jimerson DC, Klein WJ, Bunney WE, Goodwin FW (1982) Aggression, suicide, and serotonin: relationships to CSF amine metabolites. Am J Psychiatry 139:741-746.

Carette B, Poulain P (1989) Vasopressin-sensitive neurons in the lateral paraventricular nucleus area in a guinea pig slice preparation. Brain Res Bull 22:969-974.

Coccaro EF, Siever LJ, Klar H, Maurer G, Cochrane K, Cooper TB, Mohs RC, Davis KL (1989) Serotonergic studies in affective and personality disordered patients. Arch Gen Psychiatry 46:587-599.

Coccaro EF, Astill JJ, Herbert JL, Schut AG (1990) Fluoxetine treatment of impulsive aggression in DSM-III-R personality disorder patients. J Clin Psychopharmacol 10:373-375.

Coccaro, EF (1996) Neurotransmitter correlates of impulsive aggression in humans. In: Understanding aggressive behavior in children, Vol 794 (Ferris CF, Grisso, T, ed), pp 82-89. New York: New York Academy of Sciences.

Cooper KE, Kasting NW, Lederis K, Veale WL (1979) Evidence supporting a role for endogenous vasopressin in natural suppression of fever in the sheep. J Physiol (Lond) 205:33-45.

Dantzer R, Bluthe RM (1992) Vasopressin involvement in antipyresis, social communication, and social recognition: a synthesis. Crit Rev Neurobiol 6:243-255.

DeCoursey PA (1964) Function of a light response rhythm in hamsters. J Cell Comp Physiol 63:189-196.

Delville Y, Mansour KM, Yules B, Quan EW, Ferris CF (1994) Postnatal development of the vasopressinergic system in golden hamsters. Dev Brain Res 81:230-239.

Delville Y, Mansour, KM, Ferris, CF (1996a) Serotonin blocks vasopressin-facilitated offensive aggression: interactions within the ventrolateral hypothalamus of golden hamsters. Physiol Behav 59:813-816.

Delville Y, Mansour KM, Ferris CF (1996b) Testosterone facilitates aggression by modulating vasopressin receptors in the hypothalamus. Physiol Behav 60:25-29.

DeWied D (1971) Long term effect of vasopressin on the maintenance of a conditioned avoidance response in rats. Nature 232:58-60.

Ellison G (1976) Monoamine neurotoxins: selective and delayed effects on behavior in colonies of laboratory rats. Brain Res 103:81-92.

Fehm-Wolfsdorf G, Bacholz G, Born J, Voight K, Fehm HL (1988) Vasopressin but not oxytocin enhances cortical arousal: an integrative hypothesis on the behavioral effects of neurohypophyseal hormones. Psychopharmacology 94:496-500.

Ferris CF (1992) Role of vasopressin in aggressive and dominant/ subordinate behaviors. In: Oxytocin and maternal, sexual, and social behaviors, Vol 652 (Pedersen CA, Caldwell JD, Jirikowski GF, Insel TR, eds), pp 212-226. New York: New York Academy of Sciences.

Ferris CF (1996) Serotonin inhibits vasopressin facilitated aggression in the syrian hamster. In: Understanding aggressive behavior in children, Vol 794 (Ferris CF, Grisso T, eds), pp 98-103. New York: New York Academy of Sciences. 
Ferris CF, Delville Y (1994) Vasopressin and serotonin interactions in the control of agonistic behavior. Psychoneuroendocrinology 19: 593-601.

Ferris CF, Potegal M (1988) Vasopressin receptor blockade in the anterior hypothalamus suppresses aggression in hamsters. Physiol Behav 44:235-239.

Ferris CF, Albers HE, Wesolowski SM, Goldman BD, Leeman SE (1984) Vasopressin injected into the hypothalamus triggers a stereotypic behavior in golden hamsters. Science 224:521-523.

Ferris CF, Pollock J, Albers HE, Leeman SE (1985) Inhibition of flank-marking behavior in golden hamsters by microinjection of vasopressin antagonist into the hypothalamus. Neurosci Lett 55:239-243.

Ferris CF, Meenan DM, Axelson JF, Albers HE (1986a) A vasopressin antagonist can reverse dominant/subordinate behavior in hamsters. Physiol Behav 38:135-138.

Ferris CF, Meenan DM, Albers HE (1986b) Microinjection of kainic acid into the hypothalamus of golden hamsters prevents vasopressindependent flank marking behavior. Neuroendocrinology 44:112-116.

Ferris CF, Singer EA, Meenan DM, Albers HE (1988) Inhibition of vasopressin-stimulated flank marking behavior by $\mathrm{V}_{1}$-receptor antagonists. Eur J Pharmacol 154:153-159.

Ferris CF, Axelson JF, Martin AM, Roberge LR (1989) Vasopressin immunoreactivity in the anterior hypothalamus is altered during the establishment of dominant/subordinate relationships between hamsters. Neuroscience 29:675-683.

Ferris CF, Irvin RW, Potegal M, Axelson JF (1990) Kainic acid lesion of vasopressinergic neurons in the hypothalamus disrupts flank marking behavior in golden hamsters. J Neuroendocrinol 2:123-129.

Ferris CF, Pilapil CG, Hayden-Hixson D, Wiley RG, Koh ET (1992) Evidence for functionally and anatomically distinct populations of vasopressinergic magnocellular neurons in the golden hamster. J Neuroendocrinol 4:193-205.

Ferris CF, Delville Y, Gronka Z, Luber-Narod J, Insel TR (1993) An iodinated vasopressin antagonist blocks flank marking and selectively labels neural binding sites in golden hamsters. Physiol Behav 54:737-747.

Giles H, Lansdell SJ, Fox P, Lockyer M, Hall V, Martin GR (1994) Characterization of a $5-\mathrm{HT}_{1 \mathrm{~B}}$ receptor on $\mathrm{CHO}$ cells: functional responses in the absence of radioligand binding. Br J Pharmacol 112:317P.

Green JG, Gillette R (1983) Patch- and voltage-clamp analysis of cyclic AMP-stimulated inward current underlying neurone bursting. Nature 306:784-785.

Grzonka Z, Lammek B, Kaspryzykowski F, Gazis D Schwartz IL (1983) Synthesis and some pharmacological properties of oxytocin and vasopressin analogues with sarcosine or $N$-methyl-L-alanine in position 7 . J Med Chem 26:555-559.

Guan X-M, McBride WJ (1988) Fluoxetine increases the extracellular levels of serotonin in the nucleus accumbens. Brain Res Bull 21:43-46

Haug M, Wallian L, Brain PF (1990) Effects of 9-OH-DPAT and fluoxetine on activity and attack by female mice towards lactating intruders. Gen Pharmacol 21:845-849.

Higley JD, Mehlman PT, Taub DM, Higley SB, Suomi SJ, Linnoila M, Vickers JH (1992) Cerebrospinal fluid monoamine and adrenal correlates of aggression in free-ranging rhesus monkeys. Arch Gen Psychiatry 49:436-441.

Hoyer D, Engel G, Kalkman HO (1985) Characterization of 5-HT recognition sites in rat brain: binding studies with $(-)\left[{ }^{125} \mathrm{I}\right]$ iodocyanopindolol. Eur J Pharmacol 118:1-12.

Johnston RE (1975) Scent marking by male golden hamsters (Mesocricetus auratus). I. Effects of odors and social encounters. Z Tierpsychol 37:75-98.

Kavoussi RJ, Liu J, Coccaro EF (1994) An open trial of sertraline in personality disordered patients with impulsive aggression. J Clin Psychiatry 55:137-141.

Koolhaas JM, Van den Brink THC, Roozendal B, Boorsma F (1990) Medial amygdala and aggressive behavior: interaction between testosterone and vasopressin. Aggressive Behav 16:223-229.

Koolhaas JM, Moor E, Hiemstra Y, Bohus B (1991) The testosteronedependent vasopressinergic neurons in the medial amygdala and lateral septum: involvement in social behaviour of male rats. In: Vasopressin (Jard S, Jamison R, eds), pp. 213-219. Paris: INSERM/John Libbey Eurotext.

Kruesi MJP, Rapport JL, Hamberger S, Hibbs E, Potter WZ, Lenane M, Brown GL (1990) CSF metabolites, aggression, and impulsivity in dis- ruptive behavior disorders of children and adolescents. Arch Gen Psychiatry 47:419-426.

Kyes RC, Botchin MB, Kaplan JR, Manuck SB, Mann JJ (1995) Aggression and brain serotonergic responsivity: response to slides in male macaques. Physiol Behav 57:205-208.

Linnoila M, Virkkunen M, Scheinin M, Nuutila A, Rimon R, Goodwin FK (1983) Low cerebrospinal fluid 5-HIAA concentration differentiates impulsive from nonimpulsive violent behavior. Life Sci 33:2609-2614.

Liou SY, Albers HE (1989) Single unit response of suprachiasmatic neurons to arginine vasopressin (AVP) is mediated by a $V_{1}$-like receptor in the hamster. Brain Res 477:336-343.

McMillen BA, Scott SM, Williams HL, Sanghera MK (1987) Effects of gepirone, an aryl-piperazine anxiolytic drug, on aggressive behavior and brain monoaminergic neurotransmission. Naunyn Schmiedebergs Arch Pharmacol 335:454-464.

Mehlman PT, Higley JD, Faucher I, Lilly AA, Taub DM, Vickers J, Suomi SJ, Linnoila M (1994) Low CSF 5-HIAA concentration and severe aggression and impaired impulse control in nonhuman primates. Am J Psychiatry 151:1485-1491.

Moss RL, Urban I, Cross BA (1972) Microelectrophoresis of cholinergic and aminergic drugs on paraventricular neurons. Am J Physiol 223:310-318.

Muhlethaler M, Dreifuss JJ, Gahwiler BH (1982) Vasopressin excites hippocampal neurons. Nature 296:749-751.

Murphy TJ, Bylund DB (1989) Characterization of serotonin-1B receptors negatively coupled to adenylate cyclase in OK cells, a renal epithelial cell line from the Opossum. J Pharmacol Exp Ther 249:535-543.

Ogren SO, Holm AC, Renyi AL, Ross SB (1980) Anti-aggressive effect of zimelidine in isolated mice. Acta Pharmacol Toxicol 47:71-74.

O'Keane V, Moloney E, O'Neill H, O'Connor A, Smith C, Dinan TG (1992) Blunted prolactin responses to D-fenfluramine in sociopathy: evidence for subsensitivity of central serotonergic functions. Br J Psychiatry 160:643-646.

Olivier B, Mos J (1990) Serenics, serotonin and aggression, In: Current and future trends in anticonvulsant, anxiety, and stroke therapy (Meldrum BS, Williams M, eds), pp 203-230. New York: Wiley.

Olivier B, Mos J, Van der Heyden J, Hartog J (1989) Serotonergic modulation of social interactions in isolated male mice. Psychopharmacology 97:154-156.

Olivier B, Mos J, van Oorschot R, Hen R (1995) Serotonin receptors and animal models of aggressive behavior. Pharmacopsychiatry [Suppl 2] 28:80-90.

Perry KW, Fuller RW (1992) Effect of fluoxetine on serotonin and dopamine concentration in microdialysis fluid from rat striatum. Life Sci 50:1683-1690.

Peters S, Kreulen DL (1985) Vasopressin-mediated slow EPSP in a mammalian sympathetic ganglion. Brain Res 339:126-129.

Pittman QJ, Veale WL, Lederis K (1982) Central neurohypophyseal pathways: interactions with endocrine and other autonomic functions. Peptides 5:515-520.

Potegal M, Ferris CF (1990) Intraspecific aggression in male hamsters is inhibited by intrahypothalamic vasopressin-receptor antagonist. Aggressive Behav 15:311-320.

Raggenbass M, Dubois-Dauphin M, Tribollet E, Dreifuss JJ (1988) Direct excitatory action of vasopressin in the lateral septum of the rat brain. Brain Res 459:60-69.

Raggenbass M, Tribollet E, Dubois-Dauphin M, Dreifuss JJ (1989) Vasopressin receptors of the vasopressor $\left(\mathrm{V}_{1}\right)$ type in the nucleus of the solitary tract of the rat mediate direct neuronal excitation. J Neurosci 9:3929-3936.

Raggenbass M, Goumaz M, Sermasi E, Tribollet E, Dreifuss JJ (1991) Vasopressin generates a persistent voltage-dependent sodium current in a mammalian motoneuron. J Neurosci 11:1609-1616.

Sanchez C, Hyttel J (1994) Isolation-induced aggression in mice: effects of 5-hydroxytryptamine uptake inhibitors and involvement of postsynaptic 5- $\mathrm{HT}_{1 \mathrm{~A}}$ receptors. Eur J Pharmacol 264:241-247.

Saudou F, Amara DJ, Dierich A, LeMeur M, Ramboz S, Segu A, Buhot M-C, Hen R (1994) Enhanced aggressive behavior in mice lacking 5- $\mathrm{HT}_{1 \mathrm{~B}}$ receptor. Science 265:1875-1878.

Sawchenko PE, Swanson LW, Steinbusch HWM, Verhofstad AAJ (1983) The distribution of cells of origin of serotonergic inputs to the paraventricular and supraoptic nuclei of the rat. Brain Res 277:355-360.

Schoeffter P, Hoyer D (1989) 5-Hydroxytryptamine 5-HT $1 \mathrm{~B}$ and 5-HT receptors mediating inhibition of adenylate cyclase activity. Naunyn Schmiedebergs Arch Pharmacol 340:285-292. 
Schoeffter P, Pfeilschifter J, Bobirnac I (1995) 5-Hydroxytryptamine 5-HT1B receptors inhibiting cyclic AMP accumulation in rat renal mesangial cells. Naunyn Schmiedebergs Arch Pharmacol 351:35-39.

Sijbesma H, Schipper J, De Kloet ER (1990) The anti-aggressive drug eltoprazine preferentially binds to $5-\mathrm{HT}_{1 \mathrm{~A}}$ and $5-\mathrm{HT}_{1 \mathrm{~B}}$ receptor subtypes in rat brain: sensitivity to guanine nucleotides. Eur $\mathrm{J}$ Pharmacol 187:209-223.

Sijbesma H, Schipper J, De Kloet ER, Mos J, van Aken H, and Olivier B

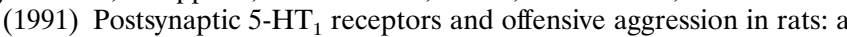
combined behavioral and autoradiographic study with eltoprazine. Pharmacol Biochem Behav 38:447-458.

Vergnes M, Depaulis A, Boehrer A, Kempf E (1988) Selective increase of offensive behavior in the rat following intrahypothalamic 5,7-DHTinduced serotonin depletion. Behav Brain Res 29:85-91.
Virkkunen M, Goldman D, Nielsen DA, Linnoila M (1995) Low brainserotonin turnover rate (low CSF 5-HIAA) and impulsive violence. J Psychiat Neurosci 20:271-275.

Winslow J, Hastings N, Carter C, Harbaugh C, Insel T (1993) A role for central vasopressin in pair bonding in monogamous prairie voles. Nature 365:545-548.

Yodyingyuad U, de la Riva C Abbott DH, Herbert J, Keverne EB (1985) Relationship between dominance hierarchy, cerebrospinal fluid levels of amine transmitter metabolites (5-hydroxyindole acetic acid and homovanillic acid) and plasma cortisol in monkeys. Neuroscience $16: 851-858$

Zucker I, Stephan FK (1973) Light-dark rhythms in hamster eating, drinking and locomotor behaviors. Physiol Behav 11:239-250. 